\title{
HEAT SYNCHRONIZATION OF CELL DIVISION IN TETRAHYMENA THERMOPHILA AND A MUTANT, NPI, WITH A TEMPERATURE SENSITIVE DEFECT FOR ORAL DEVELOPMENT
}

\author{
by \\ PETER B. SUHR-JESSEN \\ Biological Institute of the Carlsberg Foundation, \\ 16 Tagensvej, DK-2200 Copenhagen $\mathrm{N}$
}

Keywords: Tetrahymena thermophila, heat shocks, synchrony, vacuoleless mutant

Optimal conditions for induction of synchronous cell division in Tetrahymena thermophila have been investigated. Wild type cells and a mutant, NP1, with temperature sensitive oral development have been used. NP1 forms no food vacuoles after long exposures to $37^{\circ} \mathrm{C}$ or higher temperatures.

According to one temperature regime both clones were grown at $30^{\circ} \mathrm{C}$ and exposed to five $30 \mathrm{~min}$ heat shocks at $42.3^{\circ} \mathrm{C}$ spaced $30 \mathrm{~min}$ apart. This treatment resulted in $80 \%$ and in $50 \%$ increase in cell number over $15 \mathrm{~min}$ intervals placed at the time of the first and the second synchronized cell division, respectively. NP1 formed food vacuoles at the same rate as wild type cells.

According to a second temperature regime the cells were grown at $30^{\circ} \mathrm{C}$ and heat shocks at $41.8^{\circ} \mathrm{C}$ were spaced one cell generation apart. This treatment resulted in division of about $95 \%$ of the cells within a one hour period between the sixth and seventh shock.

Heat shocks were also applied to cells grown at $37^{\circ} \mathrm{C}$. Five shocks at $43.1^{\circ} \mathrm{C}$ spaced $30 \mathrm{~min}$ apart synchronized cell divisions of wild type cells but not of mutant cells.

\section{INTRODUCTION}

The first induction of synchronous division in mass cultures of animal cells was performed by SCHERBAUM and ZEUTHEN in the early fifties (25). They employed the free-living ciliate Tetrahymena pyriformis and about $85 \%$ of the cell population underwent at least two syn- chronous divisions. Such cultures were obtained after a series of exposures to elevated temperature spaced $30 \mathrm{~min}$ apart ("multi-shock program *), and they allow standard chemical and physiological techniques to be used in studies of the vegetative cell cycle (25). As the effects of the heat shocks became better un- 
derstood ZEUTHEN improved the method by spacing the shocks one cell generation apart ("one heat shock per cell cycle", (33)).

In contrast to $T$. pyriformis which is amicronucleate, T. thermophila has a macroand a micronucleus, and it can be induced to exhibit sexual cell cycles; during the latter meiosis and cross fertilization takes place (11, $15,23)$. This allows mutant isolation and genetic dissection of the life cycle of the cell. Recent advances in Tetrahymena genetics $(2,19,20$, 26) have generated many new mutants some of which are defective in cell division $(5,9)$, oral development $(21,27,28)$ and phagocytosis (28). Previously, cell division in T. thermophila has been synchronized by use of the smulti heat shock program $(10,13)$ and in this laboratory KIRSTEN HAMBURGER obtained promising preliminary results with wone heat shock per cell generation (personal communication).

It was the purpose of the present study to optimize the conditions for the induction of synchronous cell divisions in wild type $T$. thermophila by use of heat shocks and to investigate if a mutant defective in oral morphogenesis (NP1) can be synchronized. This was of interest because oral morphogenesis may play a role in allowing cell divisions to be synchronized $(6,10,17,30,35)$.

This work shows that whereas wild type and the mutant NP1 can both be synchronized with respect to cell division under conditions which permit oral development, the mutant can not be synchronized when grown at a temperature which is restrictive for oral development. It is also demonstrated that synchronized mutant cells form food vacuoles at the same rate as wild type cells, and that food vacuole formation ceases during cell division $(4,12,14)$.

\section{MATERIALS AND METHODS}

Tetrahymena thermophila, (earlier $T$. pyriformis, syngen 1) inbred strain $D$, mating type III (DIII) (16), originally obtained from D. L. NANNEY, and a nitrosoguanidine-induced mutant NP1 (wt/wt ( $\mathrm{vac}^{-}$, mating type III)) were employed. NP1 has a macronuclear mutation for a heat sensitive development of the oral apparatus (OA) which allows the development of a functional $\mathrm{OA}$ at $30^{\circ} \mathrm{C}$ but not at $37^{\circ} \mathrm{C}(21,27)$. Stocks of both clones were grown axenically at $30^{\circ} \mathrm{C}$ and $37^{\circ} \mathrm{C}$ with daily dilutions to about 400 cells per ml. The stocks at each temperature were tested daily for food vacuole formation using India ink, and were used only if the NPI stock at $37^{\circ} \mathrm{C}$ contained less than $1 \%$ vacuole-forming cells, while the three other cultures all contained more than $90 \%$ vacuole forming cells.

Autoclaved $2 \%$ proteose peptone broth (Difco laboratories) was supplemented with sodium citrate $(2 \mathrm{mM}), \quad \mathrm{FeCl}_{3} \cdot 6 \mathrm{H}_{2} \mathrm{O} \quad(1 \mathrm{mM})$, $\mathrm{CuSO}_{4} \cdot 5 \mathrm{H}_{2} \mathrm{O}(30 \mu \mathrm{M})$ and folinic acid $(1.7 \mu \mathrm{M})$. This medium (EPP) allows NP1 to grow without forming food vacuoles (22) with a generation time which is only about 20 min longer than that for wild type cells (unpublished).

The equipment and methods have been previously described by ZEUTHEN and coworkers (34). Cells were grown axenically in $100 \mathrm{ml}$ Erlenmeyer flasks with screw caps containing 10 to $30 \mathrm{ml}$ nutrient medium. The flasks were submerged in a water bath and constantly shaken at a moderate speed; under these conditions oxygen was not a growth limiting factor. The temperature in the water bath was controlled to $0.1^{\circ} \mathrm{C}$. A 1,000 Watt heater and a cooling loop were coupled to the temperature controller. Temperature changes from $30^{\circ} \mathrm{C}$ to $44^{\circ} \mathrm{C}$ and from $44^{\circ} \mathrm{C}$ to $30^{\circ} \mathrm{C}$ took place in less than 5 minutes. Inoculum size was usually between 400 and 1,000 cells per ml and resulted in $10-50,000$ cells per $\mathrm{ml}$ at the end of the heat shock treatment.

Population growth was followed by withdrawal of duplicate samples of known volumes at 10 or $15 \mathrm{~min}$ intervals. One of these was fixed immediately with formaldehyde (final conc., $2 \% \mathrm{v} / \mathrm{v}$ ) and counted later by use of an electronic cell counter. The other was immediately studied microscopically and the division index of the live culture was estimated (32). These two methods agreed well in all cases.

Food vacuole formation was followed by the use of ink tests (21). Samples were incubated for $10 \mathrm{~min}$ at $30^{\circ} \mathrm{C}$ with an equal volume of a prewarmed $0.4 \%$ ink solution (India ink in EPP) and then fixed with formaldehyde (final conc., 
$2 \% \mathrm{v} / \mathrm{v}$ ). From each sample, 200 cells were examined by use of a Reichert compound light microscope $(12.5 \times 40)$ and scored as dividers or non-dividers; the number of vacuoles within each cell was also determined.

\section{RESULTS}

Two heat shock techniques for the induction of synchronous cell divisions in $\mathrm{T}$. thermophila have been used $(25,33)$. Both involve five parameters: the shock- and intershock temperatures, the duration of the shock and intershock periods, and the number of shocks.

NP1 is characterized by its ability to form a functional oral apparatus (OA) at $30^{\circ} \mathrm{C}$ but not at $37^{\circ} \mathrm{C}$, while wild type cells form functional OAs at both temperatures; therefore these were intershock temperatures used with both clones. Throughout most of the study the durations of the shock and intershock periods were $30 \mathrm{~min}$.

Figure 1 show results from experiments in which NP1 was grown at $30^{\circ} \mathrm{C}$ and treated with five $30 \mathrm{~min}$ heat shocks spaced $30 \mathrm{~min}$ apart. The shock temperature was varied, and it is

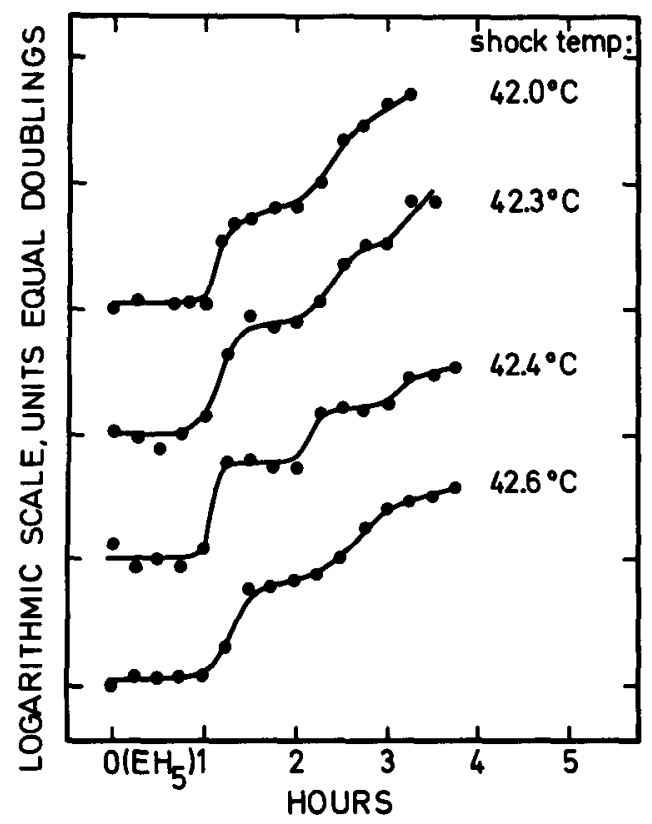

Figure 1. Effects of different shock temperatures on NP1 cells grown at $30^{\circ} \mathrm{C}$ and treated with five $30 \mathrm{~min}$ heat shocks spaced $30 \mathrm{~min}$ apart. Time zero is the end of the fifth heat shock.

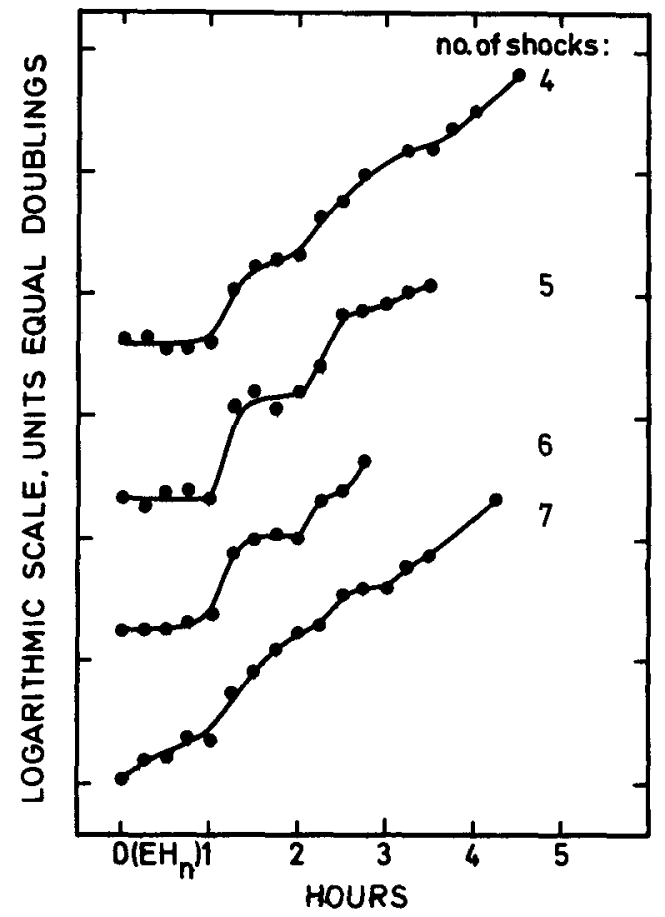

Figure 2. Effects of different numbers of shock temperatures. NP1 cells were grown at $30^{\circ} \mathrm{C}$ and treated with $30 \mathrm{~min}$ heat shocks at $42.3^{\circ} \mathrm{C}$ spaced $30 \mathrm{~min}$ apart. Time zero is the end of shock treatment.

judged that $42.3^{\circ} \mathrm{C}$ induces the best division synchrony. Increase or decrease of the shock temperature by as little as $0.1^{\circ} \mathrm{C}$ influences the division synchrony negatively (Fig. 1 , and unpublished).

In another series of experiments the number of heat shocks was varied while the shock temperature was kept at $42.3^{\circ} \mathrm{C}$. Figure 2 suggests that five or six heat shocks result in the best division synchrony of NP1.

ZEUTHEN and collaborators showed that the "multi heat shock program", when applied to T. pyriformis, resulted in cellular amounts of DNA and protein which were higher than those found in logarithmically growing cells $(1,24$, 25). Such effects were minimized when the cells were synchronized with the "one heat shock per cell cycle" procedure (33). Figure 3A, B and $\mathrm{C}$ show data from experiments in which NP1 was grown at $30^{\circ} \mathrm{C}$ and treated with heat shocks spaced one cell generation apart. The increases in population densities at the time of 


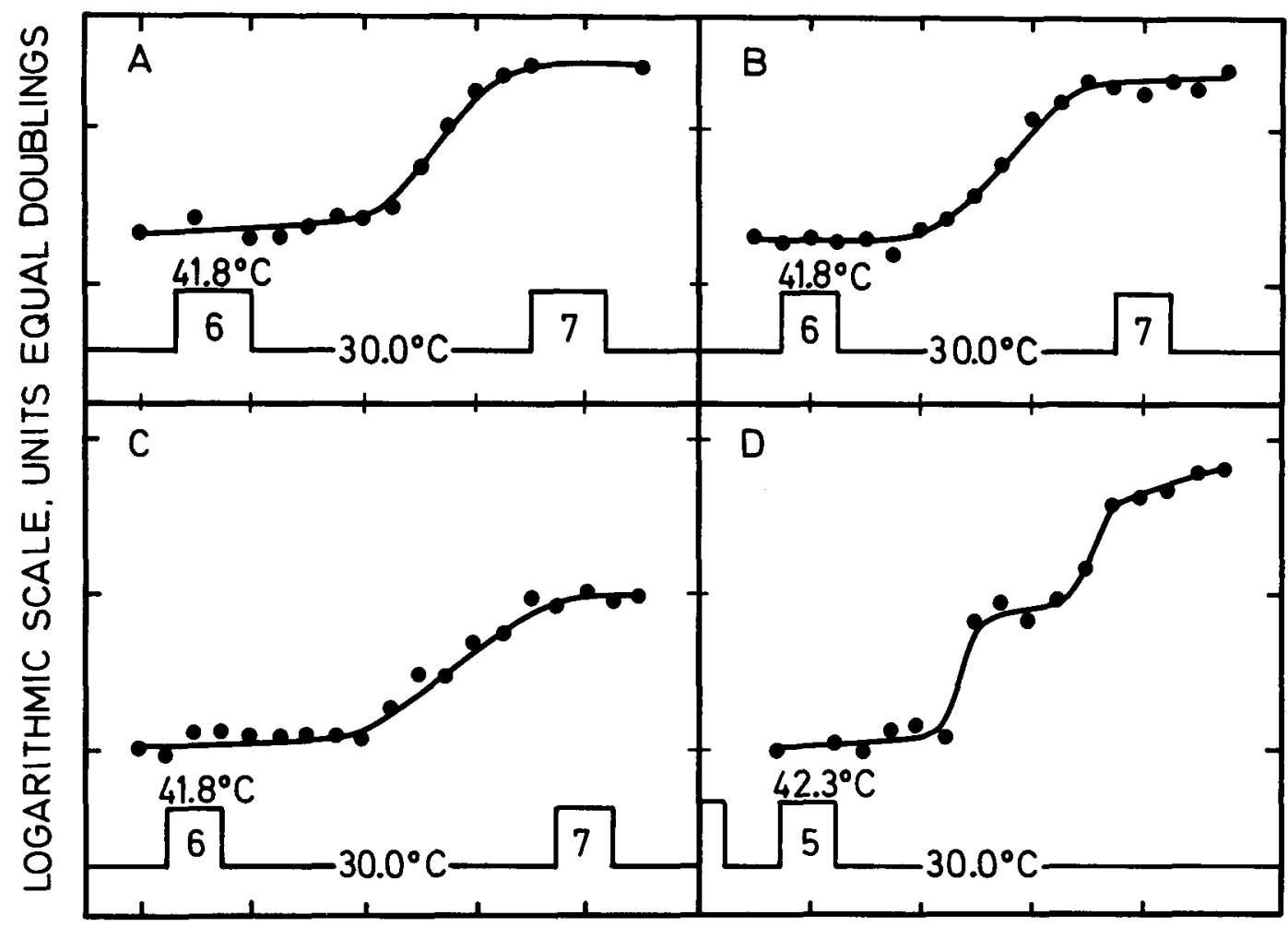

HOURS.UNITS EQUAL ONE HOUR

Figure 3. The best synchronizations of cell divisions obtained with NP1 cells grown at $30^{\circ} \mathrm{C}$ using "one heat shock per cell cycle" (panels A, B and C) compared to the synchronization regularly obtained using the "multi shock procedure" (Panel D). The numbers in the temperature profile indicate number of heat shocks.

the synchronous divisions are $95 \%$, but cell divisions occur over a long period (more than one hour). Figure 3D shows the results obtained when NPI cells are treated with 5 heat shocks at $42.3^{\circ} \mathrm{C}$ spaced $30 \mathrm{~min}$ apart. About $80 \%$ of the cells divide within $15 \mathrm{~min}$ at the time of the first division maximum and about $50 \%$ within $15 \mathrm{~min}$ at the time of the second. The optimal shock temperature in the one heat shock per cell cycle " regime is $41.8^{\circ} \mathrm{C}$ while it is $42.3^{\circ} \mathrm{C}$ for the "multi shock " program. The reason for this difference is unknown.

Figure 4 shows time between the end of heat shock $5\left(\mathrm{EH}_{5}\right)$ and the appearance of the first newly divided cell (ID), as a function of the shock temperature in the "multi heat shock program". It is seen that shock temperatures between $42.0^{\circ} \mathrm{C}$ and $42.6^{\circ} \mathrm{C}$ give rise to a $60 \mathrm{~min}$ period with no cell divisions. The time between

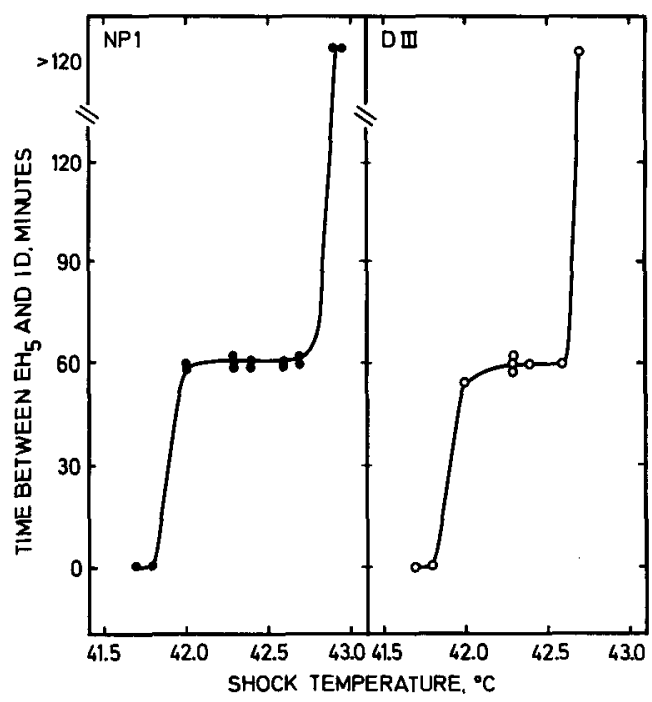

Figure 4. Time between $\mathrm{EH}_{3}$ and observation of the first dividing cell as a function of the shock temperature for cells grown at $30^{\circ} \mathrm{C}$. 
$\mathrm{EH}_{5}$ and division of $50 \%$ of the cells was 10 to 20 min longer (not shown). Temperatures lower than $41.8^{\circ} \mathrm{C}$ do not fully block cell divisions while temperatures above $42.8^{\circ} \mathrm{C}$ block cell divisions for several hours or kill the cells. The results are consistent with those for $T$. pyriformis $(29,33)$.

The function of the $\mathrm{OA}$ as measured by rate of food vacuole formation in wild type (wt) and $\mathrm{NP1}$ cells grown at $30^{\circ} \mathrm{C}$ is shown in Fig. 5 . In logarithmically growing cultures, $10 \%$ of the cells (the dividers) form no vacuoles during a 10 min incubation period with India ink while the

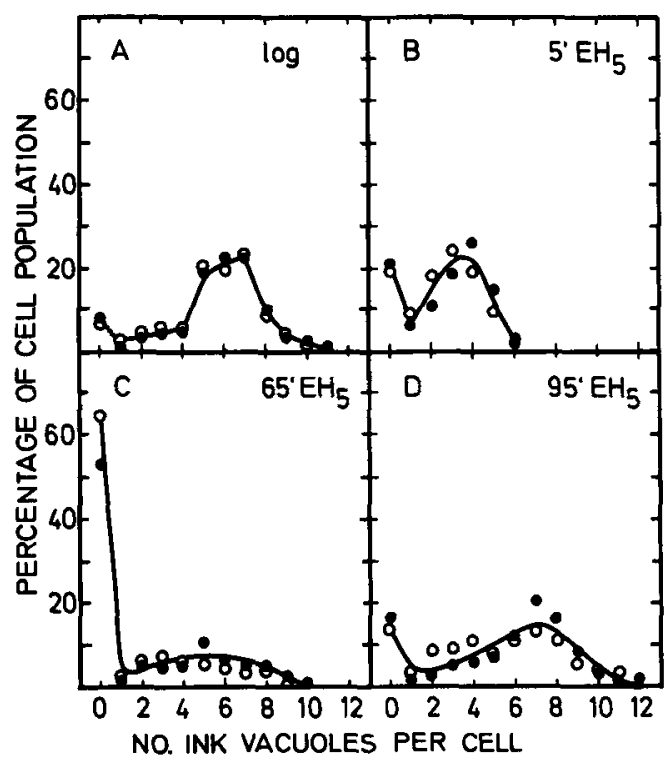

Figure 5. Food vacuole formation in cells grown logarithmically at $30^{\circ} \mathrm{C}$ (panel A) and in cells treated with five $30 \mathrm{~min}$ heat shocks at $42.3^{\circ} \mathrm{C}$ spaced $30 \mathrm{~min}$ apart (panels B, C and D). The first synchronous division takes place around $65 \mathrm{~min}$ after end of shock treatment $\left(65^{\prime} \mathrm{EH}_{5}\right)$. Closed circles: DIII. Open circles: NP1.

rest form 1 to 11 vacuoles (Fig. 5A). The average rate of food vacuole formation among vacuole formers is $0.61 \mathrm{vac} \cdot \mathrm{min}^{-1}(\mathrm{wt})$ and 0.60 vac. $\mathrm{min}^{-1}$ (NP1). In heat synchronized cultures, vacuole formation is somewhat disturbed. Immediately after shock treatment (0-10 min after $\mathrm{EH}_{5}$ ) $20 \%$ of the cells are non-vacuole formers and the average rate among vacuole formers is
$0.35 \mathrm{vac} \cdot \mathrm{min}^{-1}(\mathrm{wt})$ and $0.30 \mathrm{vac} \cdot \mathrm{min}^{-1}(\mathrm{NP1})$ (Fig. 5B). During the first synchronous division more than $50 \%$ of the cells (the dividers) are non-vacuole formers. The rest of the cells have almost regained normal function of the $O A$ and form in average 0.52 vac. $\mathrm{min}^{-1}$ (wt) and 0.45 vac. $\min ^{-1}$ (NP1) (Fig. 5C). Between the first and the second synchronous division the fraction of non-vacuole formers decreases to about $15 \%$ and the rest of the cells form in average $0.67 \mathrm{vac} \cdot \mathrm{min}^{-1}(\mathrm{wt})$ and $0.59 \mathrm{vac} \cdot \mathrm{min}^{-1}$ (NP1) (Fig. 5D). Oral morphogenesis prior to the first division must be normal in NP1, otherwise we would have found a higher fraction of NP1 cells which did not form food vacuoles than the fraction found in wild type cells (compare panels D and $\mathrm{A}$ in Fig. 5).

NP1 was grown at $37^{\circ} \mathrm{C}$ before, between and after five successive half-hour heat shocks to the temperatures indicated in Fig. 6, which shows cell multiplication after the shocks. By and large, growth is undisturbed by temperatures below and at $43.1^{\circ} \mathrm{C}$ but is completely

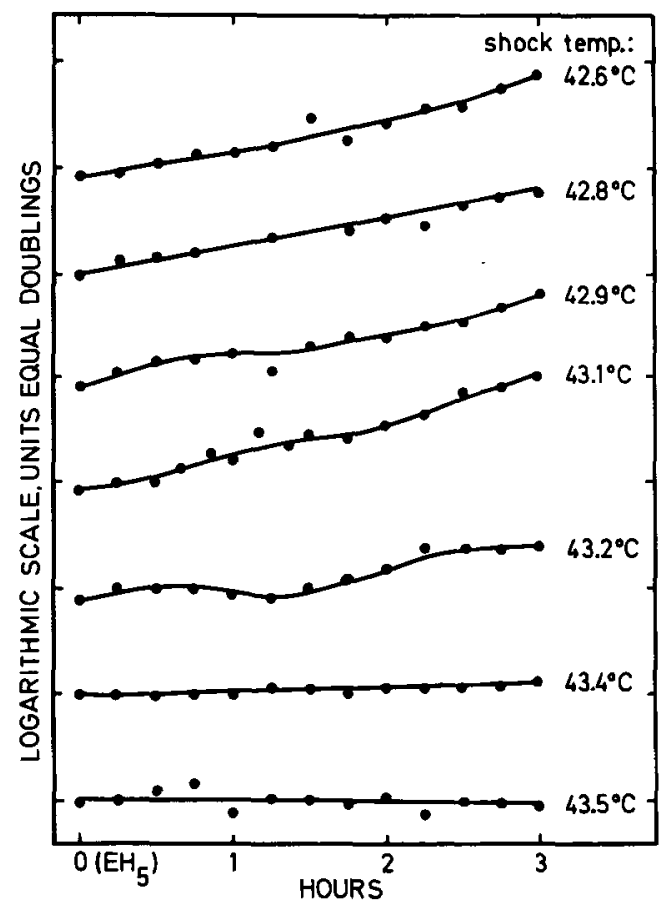

Figure 6. Effects of different shock temperatures on NPI cells grown at $37^{\circ} \mathrm{C}$ and treated with five $30 \mathrm{~min}$ heat shocks spaced $30 \mathrm{~min}$ apart. 


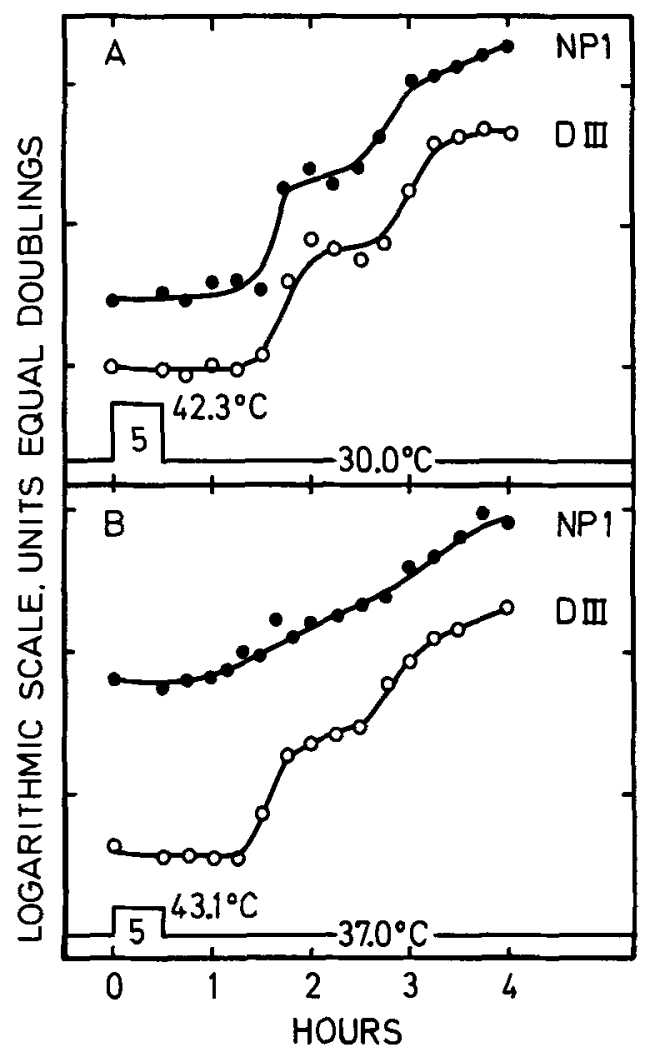

Figure 7. Optimal conditions for induction of synchronous cell divisions in cultures grown at $30^{\circ} \mathrm{C}$ (panel A) and at $37^{\circ} \mathrm{C}$ (panel B).

blocked by temperature shocks at $43.4^{\circ} \mathrm{C}$ and $43.5^{\circ} \mathrm{C}$. As indicated also in Fig. 7B no synchrony has been induced, which is contrary to what is obtained with the wild type (DIII) after 5 heat shocks $\left(43.1^{\circ} \mathrm{C}\right.$, optimal for DIII grown at $37^{\circ} \mathrm{C}$ ). As shown in Fig. 7A, DIII shows somewhat better synchrony when grown at $30^{\circ} \mathrm{C}$ and shocked at $42.3^{\circ} \mathrm{C}$ (optimal for this growth temperature). NP1 cells exposed to similar treatment exhibit equally good synchrony. The final comparison is between mutant cells treated as in panels B and A of Fig. 7; this is lack of synchrony versus synchrony and at the same time it is lack of OA formation versus $O A$ formation. Capacity for synchrony induction appears to be tightly coupled to the development of a new $O A$ in each cell generation. It is gratifying to be able to note this because description of oral morphogenesis has served as one of several monitors of cell syn- chrony induction in much of the earlier work on heat shock induced cell division in $\mathrm{T}$. pyriformis.

\section{DISCUSSION}

Cell division in $\mathrm{T}$. thermophila grown at $30^{\circ} \mathrm{C}$ can be synchronized by the use of heat shocks spaced either $30 \mathrm{~min}$ or one cell cycle apart; the former method yields the highest degree of synchrony (Fig. 3). The shock temperatures inducing synchronous cell divisions range from $42.0^{\circ} \mathrm{C}$ to $42.6^{\circ} \mathrm{C}$ with $42.3^{\circ} \mathrm{C}$ as the optimum (Fig. 4).This interval is narrow compared to the $3^{\circ} \mathrm{C}$ interval $\left(32-35^{\circ} \mathrm{C}\right)$ found for $\mathrm{T}$. pyriformis $(29,33)$, thus temperature control is critical. Under optimal conditions about $80 \%$ of the cells divide during the first synchronous division between 60 and $75 \mathrm{~min}$ after $\mathrm{EH}_{5}$ and about $50 \%$ of the cells divide again (second synchronous division) 60 to $75 \mathrm{~min}$ later (Fig. 7A). The degree of synchrony is lower than that found for the amicronucleate $T$. pyriformis (25) though as high or higher than that found earlier for $T$. thermophila $(10,13)$. The reason for this difference between species is unknown.

The rates of food vacuole formation in wild type and NPI cells are identical at $30^{\circ} \mathrm{C}$ both when log phase cells and when synchronized cells are compared (Fig. 5). The cells are able to form food vacuoles after the shock treatment with the exeption of a 20-30 min period around cell division coincident with the remodeling of the deep fiber $(3,4,6,17)$. This is consistent with similar observations on logarithmically growing wild type $\mathrm{T}$. thermophila and on $\mathrm{T}$. pyriformis $(4,12,14,18,31$, and unpublished observations).

Is development of a functional OA obligatory for heat synchronization of cell division in Tetrahymena? Such a connection has been suggested by ZEUTHEN and WILLIAMS (35) and others $(3,6,7,10,17,30)$. NP1 does not have a functional $\mathrm{OA}$ when grown at $37^{\circ} \mathrm{C}$ and it keeps multiplying almost completely asynchronously during and following heat treatment (Fig. 7), which agrees with the cited model (35). However, the present results make it difficult to accept the model of ZEUTHEN and WILLIAMS in its primary form. Morphological studies of NP1 


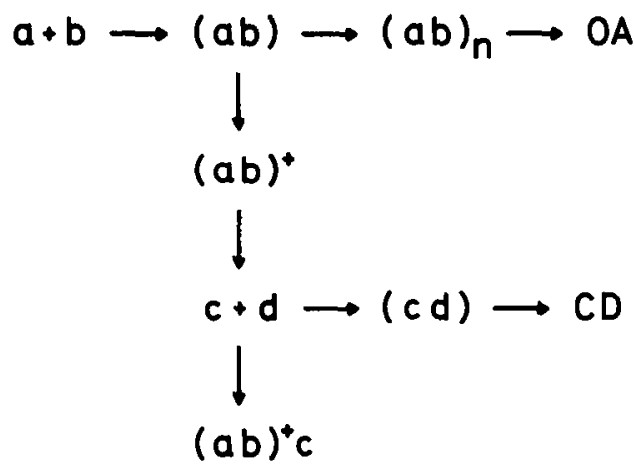

Figure 8. A model for regulation of oral development and cell division in Tetrahymena.

growing at $37^{\circ} \mathrm{C}$ suggest that oral development is blocked in stage 2 (21, unpublished results). Thus development of a functional OA can not be a condition for the cell to go from division to division, such as the primary model of ZEUTHEN and Williams suggests (35). A slight modification of their model which accounts for the additional data presented in this report is shown in Fig. 8. Compounds $a$ and $b$ (probably polypeptides) form a heat-labile precursor molecule $a b$ which polymerizes to a heat-stabile protein complex, $(a b)_{n}$, which leads to the formation of a functional $O A$. In a parallel pathway polypeptides $c$ and $d$ are required for cell division (CD). During heat shock treatment of wild type cells $a b$ is modified to $a b^{+}$, which has a high affinity for $c$ and complex $(a b)^{+} c$ is formed. Before oral development and cell division can take place compounds $a, b$ and $c$ have to be re-synthesized. At $37^{\circ} \mathrm{C}$ NP1 makes defective $a$ and complex $a b$ can not be formed. Thus cell division can proceed even during heat shock treatment. The model predicts that mutants with defects in late oral morphogenesis can be heat synchronized with respect to cell division. This remains to be tested.

The above considerations build on the assumption that the mutation(s) in NP1 reflects only at the level of oral development. This, unfortunately, is not fully correct. At $37^{\circ} \mathrm{C}$ NP1 has a generation time $10 \%$ longer than wild type cells and other yet uncovered defects can not be excluded at this stage.
The heat shock system described will be useful for studies on the timing and regulation of DNA synthesis in macro- and micronuclei (11) and for studies on the timing of the functioning of the temperature sensitive geneproduct(s) in NP1 and other mutants $(9$, 29). In addition, it provides a tool for screening for mutants super- or insensitive to heat shocks. Such mutants may provide insight into the control mechanisms for oral development, nuclear division and cell division $(8,9,17,28,30,35)$.

\section{ACKNOWLEDGEMENTS}

I wish to express my gratitude to professor ERIK ZEUTHEN, head of The Biological Institute of the Carlsberg Foundation, for providing a stimulating environment and him and Drs. $\mathrm{H}$. A. ANDERSEN, E. ORIAS, and L. RASMUSSEN for fruitful discussions.

Support from the Danish National Science Research Council and the Carlsberg Foundation to the author and from NIH to E. ORIAS (GM21067) is gratefully acknowledged.

\section{REFERENCES}

1. Andersen, H. A., C. F. Brunk \& E. Zeuthen: Studies on the DNA replication in heat synchronized Tetrahymena pyriformis. Compt. Rend. Trav. Lab. Carlsberg 38, 123-131 (1970)

2. Bruns, P. J., T. B. Brussard \& A.V, KAVKa: Isolation of homozygous mutants after induced self-fertilization in Tetrahymena. Proc. Natl. Acad. Sci. USA 73, 3243-3247 (1976)

3. Buhse, H. E., Jr. \& E. Zeuthen: Oral morphogenesis in Tetrahymena cells synchronized with one heat shock per generation. Compt. Rend. Trav. Lab. Carlsberg 39, 493-505 (1974)

4. Chapman-Andresen, C. \& J. R. Nilsson: On vacuole formation in Tetrahymena pyriformis $\mathrm{GL}$. Compt. Rend. Trav. Lab. Carlsberg 36, 405-432 (1968)

5. Doerder, F. P., J. Frankel, L. M. Jenkins \& L. E. DeBaulT: Form and pattern in ciliated protozoa; analysis of a genic mutant with altered cell shape in Tetrahymena pyriformis, syngen 1. J. Exp. Zool. 192, 237-258 (1975)

6. Frankel, J.: The effects of heat, cold, and pfluorophenylanaline on morphogenesis in syn- 
chronized Tetrahymena pyriformis GL. Compt. Rend. Trav, Lab. Carlsberg 33, 1-52 (1962)

7. Frankel, J.: The effect of nucleic acid antagonists on cell division and oral organelle development in Tetrahymena pyriformis. J. Exp. Zool. 159, 113-148 (1965)

8. Frankel, J., L. M. Jenkins \& L. E. Debault: Causal relations among cell cycle processes in Tetrahymena pyriformis. An analysis employing temperature sensitive mutants. J. Cell Biol. 71, 242-260 (1976)

9. Frankel, J., L. M. Jenkins, F. P. Doerder \& E. M. NELSEN: Mutations affecting cell division in Tetrahymena pyriformis. I. Selection and genetic analysis. Genetics 83, 489-506 (1976)

10. Gavin, R. H.: The effects of heat and cold on cellular development in synchronized Tetrahymena pyriformis. J. Protozool. 12, 302-318 (1965)

11. Gorovsky, M. A.: Macro- and micronuclei of Tetrahymena pyriformis. A model system for studying the structure and function of eukaryotic nuclei. J. Protozool. 20, 19-25 (1973)

12. Hildebrandt, A. \& F. Duspiva: Eine einfache methode zur synchronisation grösserer populationen des ciliaten Tetrahymena pyriformis (Ehrenberg). Z. Naturforsch. 24B, 747-750 (1969)

13. Holz, G. G., O. H. Scherbaum \& N. E. WILliams: The arrest of mitosis and stomatogenesis during temperature induction of synchronous division in Tetrahymena pyriformis, mating type 1, variety 1. Exptl. Cell Res. 13,618621 (1957)

14. Nachtwey, D. S. \& W. J. Dickinson: Actinomycin D: Blockage of cell division of synchronized Tetrahymena pyriformis. Exptl. Cell Res. 47, 581-595 (1967)

15. NanNey, D. L.: Nucleo-cytoplasmic interaction during conjugation in Tetrahymena. Biol. Bull. 105, 133-148 (1953)

16. NanNeY, D. L. \& J. W. McCoY: Characterization of the species of the Tetrahymena pyriformis complex. Trans. Amer. Micros. Soc. 95, 664-682 (1976)

17. Nelsen, E. M.: Division delay and abnormal oral development produced by Colchicine in Tetrahymena. J. Exptl. Zool. 175, 69-84 (1970)

18. Nilsson, J. R.: Physiological and structural studies on Tetrahymena pyriformis GL. With special reference to endocytosis and to structural changes during the cell cycle and in response to atterations in the cellular environment. Compt. Rend. Trav. Lab. Carlsberg 40, 215-335 (1976)

19. ORIAS, E. \& P. J. BRUNS: Induction and isolation of mutants in Tetrahymena. In D. M. PrescotT (ed.) Methods in Cell Biology 8, 247-282. Academic Press, N. Y. (1976)

20. Orias, E. \& E. P. Hamilton: Induction of selffertilization in conjugating Tetrahymena cells. Abstracts The Fifth International Congress Protozool. N. Y. p. 93 (1977)

21. Orias \& N. A. Pollock: Heat-sensitive development of the phagocytic organelle in a Tetrahymena mutant. Exptl. Cell Res. 90, 345-356 (1975)

22. Orias, E. \& L. RASMUSSEN: Dual capacity for nutrient uptake in Tetrahymena. IV. Growth without food vacuoles and its implications. Exptl. Cell Res. 102, 127-137 (1976)

23. RAY, C., Jr.: Meiosis and nuclear behavior in Tetrahymena pyriformis. J. Protozool. 3, 88-96 (1956)

24. Scherbaum, O.: The content and composition of nucleic acids in normal and synchronously dividing mass cultures of Tetrahymena piriformis. Exptl. Cell Res. 13, 24-30(1956)

25. Scherbaum, O. \& E. Zeuthen: Induction of synchronous cell division in mass cultures of Tetrahymena piriformis. Exptl. Cell Res. 6, 221227 (1954)

26. Sonneborn, T. M.: Genetics of Tetrahymena pyriformis: In R. C. KING (ed.). Handbook of Genetics 2, 433-467. Plenum, N. Y. (1974)

27. Silberstein, G. B., E. Orias \& N. A. Pollock: Mutant with heat-sensitive capacity for phagocytosis in Tetrahymena: Isolation and genetic characterization. Genet, Res. Cambridge 26, 11 19 (1975)

28. SUHR-JESSEN, P. B.: Mutants of Tetrahymena thermophila with defective phagocytosis. J. Cell Biol. 75, 40a (1977)

29. ThormaR, H.: Delayed division in Tetrahymena pyriformis induced by temperature changes. Compt. Rend. Trav. Lab. Carlsberg 31, 207-225 (1959)

30. WilliaMs, N. E.: Relations between temperature sensitivity and morphogenesis in Tetrahymena GL. J. Protozool. 11, 566-572 (1964)

31. WOLFE, J.: Differential density labelling and gradient centrifugation of Tetrahymena. A new procedure for selection of synchrony. Exptl. Cell Res. 77, 232-238 (1973)

32. ZeUTHEN, E.: Independent synchronization of DNA synthesis and of cell division in the same culture of Tetrahymena. Exptl. Cell Res. 61, 311325 (1970)

33. ZeUthen, E.: Synchrony in Tetrahymena by heat shocks spaced a normal cell generation apart. Exptl. Cell Res. 68, 49-60 (1971)

34. ZeutheN, E. \& L. RASMUSSEN: Synchronized cell division in protozoa. In T. T. CHEN (ed.) Research 
in Protozoology 4, 9-145. Pergamon Press, N. Y. (1972)

35. Zeuthen, E. \& N. E. Williams: Division-limiting morphogenetic processes in Tetrahymena. In E. V. CoWdry \& S. SENo (eds.) Nucleic Acid Metabolism Cell Differentiation and Cancer Growth 203-217. Pergamon Press, N. Y. (1969) 